\title{
The contribution of marine biology to biomedical research: past, present, future
}

\author{
E. Kinne-Saffran ${ }^{1,2}$ \& R. K. H. Kinne $e^{1,2}$ \\ ${ }^{1}$ Max-Planck-Institut für molekulare Physiologie, Abteilung Epithelphysiologie; \\ Postfach 102664, D-44026 Dortmund, Germany \\ and \\ ${ }^{2}$ Mount Desert Island Biological Laboratory, Salsbury Cove, Maine, USA
}

"Ask the fish of the sea, and they will declare unto thee" (Job 12:8)

\section{INTRODUCTION}

This contribution focusses on the role marine biology - or more precisely marine species or marine model systems - have played in the elucidation of basic physiological processes. Many of these have turned out to be of utmost significance in understanding the function of the human body in health and disease or in developing therapeutical means to cure human maladies. The particular usefulness of marine models in a variety of these seminal discoveries can be traced back to three main reasons: (a) Abundance of species, size of biological model system, and ready accessibility lead to an ease of experimentation. (b) In several marine species, that represent early steps in mammalian evolution, organ structure is often quite simple and organ function is highly specialized. Such "unifunctionality" contrasts to the "multifunctionality" usually found in mammalian and human tissues and facilitates the investigation of a particular function in a defined, homogeneous cell population. (c) Most importantly, it has become clear, mainly through the recent advances in molecular biology and cell biology, that biodiversity in cellular function does not require an incomprehensible number of functionally different units; it can be reduced to the existence of a limited number of families of closely related molecules that are employed by nature to perform basic cellular functions (Kinne, 1991a). These similarities allow us to draw conclusions from findings on marine organisms as to the function of a human organ with even more certainty.

In the following, mainly contributions of marine models to renal physiology and pathophysiology will be highlighted, but it should be emphasized that the role of marine models was equally important in other areas of cell research. In the area of oogenesis, spermatogenesis, cytokinesis, and reproduction, numerous studies on the eggs of sea urchins, sand dollars, and snails have laid a firm basis for our understanding of cell division and its temporal and spatial organization (Rappaport, 1991). Elasmobranch testes have recently been discovered to provide an ideal model system for the studies of different phases of spermatogenesis and the viviparous dogfish is a suitable model for 
investigations of the hormonal regulation of reproduction (Callard, 1991; Koob \& Callard, 1991). In nerve physiology, the giant axon of the squid was - and continues to be - one of the prime model systems in which the properties of numerous ion channels and ion pumps have been characterized and their role in nerve conduction identified (Boron \& Knakal, 1992; Hodgkin \& Huxley, 1952). Also the Na-K-ATPase, the primary pump maintaining intracellular ion homeostasis and cell volume, was first described by Skou in the leg nerves of crabs (Skou, 1957), thereby providing the first link of an ATP-consuming cellular reaction to the translocation of inorganic electrolytes across cell membranes (Skou, 1989). This enzyme was later found by Schatzmann (1967) to be inhibited by "cardiac glycosides" which are used for the treatment of heart failure. Until today, the sodium chloride-secreting rectal gland of the shark is one of the richest sources of this enzyme for biochemical and biophysical studies (Medzihradsky et al., 1967). The rectal gland also, very early on, played an important role in elucidating the mechanisms of hormonal regulation of salt transport and intracellular signalling - an area still pursued vigorously using this organ as model system (Schofield et al., 1991).

\section{MARINE BIOLOGY AND RENAL PHYSIOLOGY}

In Figure 1, a scheme of a mammalian nephron is represented with its proximal tubule, Henle's loop, the distal tubule and the collecting duct. In all these parts of the kidney, studies on marine organisms have contributed essential information on the function of these segments and the cellular and molecular basis for their function.

For the proximal tubule, in 1923, the question was solved whether mammalian kidneys have the capability to excrete compounds from the blood into the primary urine (Marshall \& Vickers, 1923) in addition to the - at that time - widely-accepted functions of filtration in the glomerulum and reabsorption along the tubule (Cushny, 1917). Definite proof of secretory processes in this segment could be obtained by the use of the goosefish

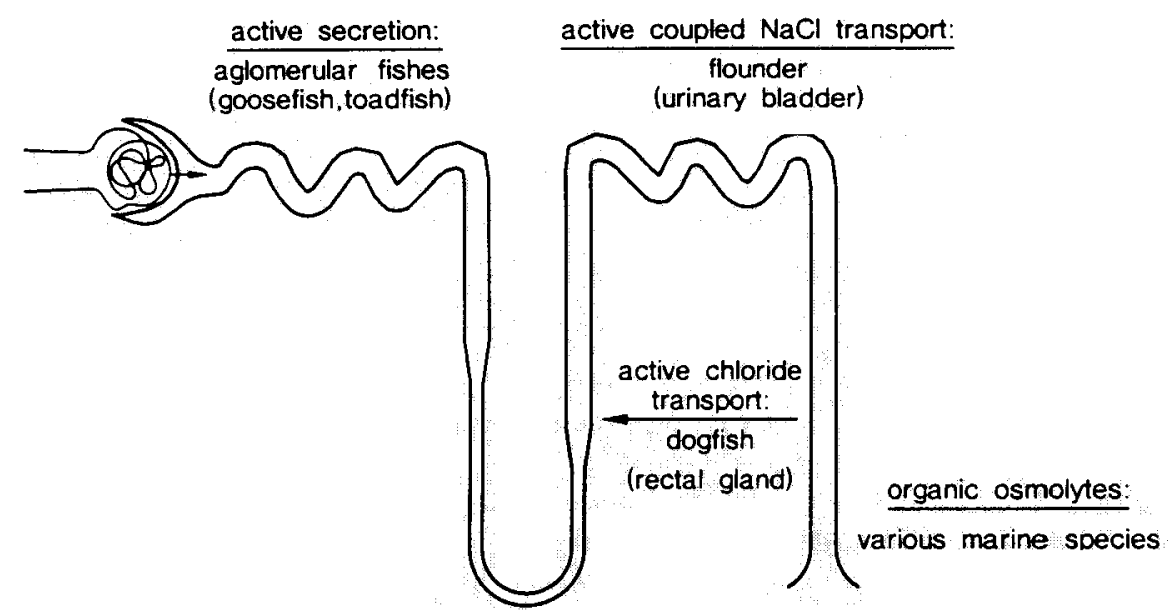

Fig. 1. Schematic representation of a mammalian (human) nephron indicating some of the main segments where marine biology has considerably contributed to elucidating the cellular and molecular mechanism of their function 
(Lophius piscatorius), i.e. an aglomerular fish, in which no filtration occurs, and substances transferred from the blood to the urine must have passed the renal cell in a secretory direction (Marshall \& Grafflin, 1928). This process was first found for a variety of organic dyes and later led to the development of contrast media to trace the urinary tract, or to measure renal blood flow. This route is still employed for the targeting of antibiotics in renal infection or of diuretics to their intratubular site of action. The cellular mechanism underlying tubular secretion was also first unveiled using fish models, such as the flounder, (Forster \& Taggart, 1950; Kinter, 1966). In Figure 2, studies are shown in which

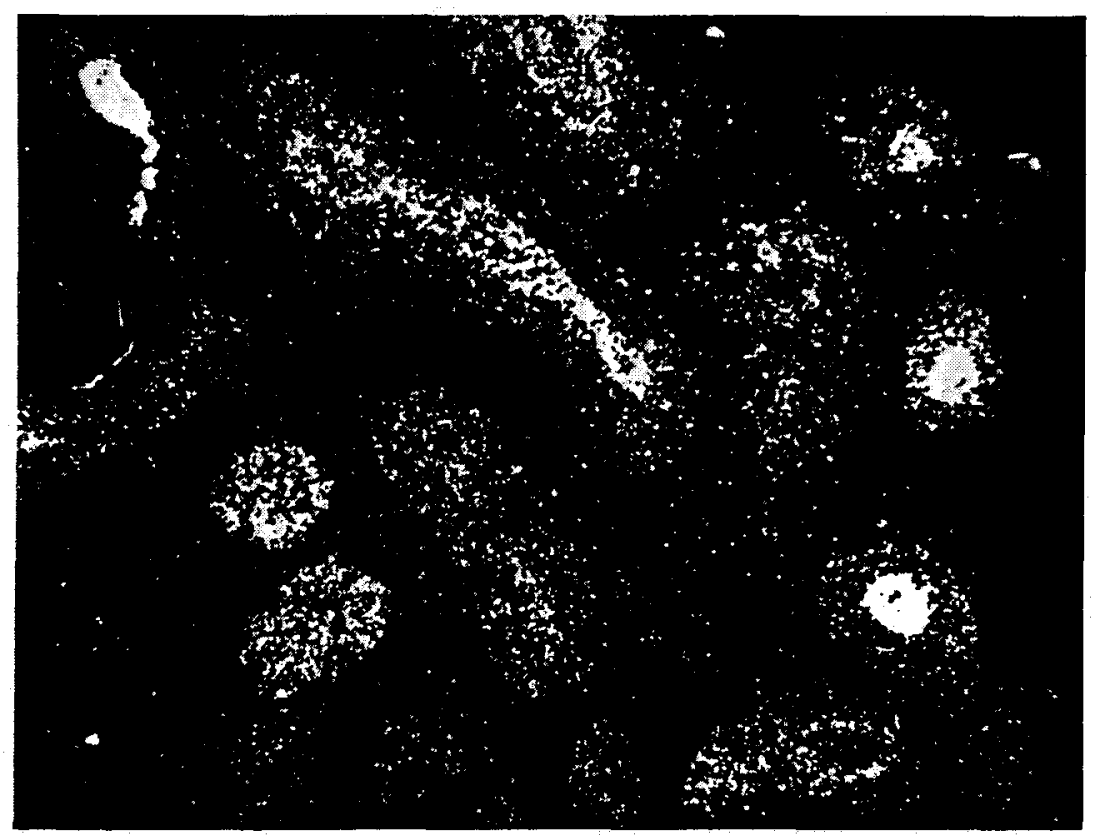

Fig. 2. ${ }^{3} \mathrm{H}$-chlorphenol red autoradiograph of proximal tubules dissected from the kidney of the winter flounder (Pseudopleuronectes americanus) and incubated for $60 \mathrm{~min}$ at $20^{\circ} \mathrm{C}$ in $10 \mu \mathrm{M}$ tritiated chlorphenol red. Individual tubules are shown both in cross and longitudinal sections in a low-magnification dark-field photomicrograph (autographic silver grains appear as white dots). For further details see Kinter, 1975 (reprinted with kind permission)

proximal tubules dissected from the flounder kidney were incubated in a bath containing a radioactively labelled weak organic acid (Kinter, 1975). The subsequently obtained autoradiograph clearly establishes that during secretion by the cells, weak organic acids are first accumulated intracellularly and then further accumulated within the tubular lumen. The driving force for the latter accumulation could be identified in flounder kidney brush border vesicles - and later also in mammalian kidneys - to be provided by the electrical potential across the brush border membrane (Eveloff et al., 1979). The mechanism of accumulation at the basal pole of the cell is depicted in Figure 3 (Kinne, 1988a; Pritchard, 1990; Shimada et al., 1987). Indirect coupling between a sodium gradient-driven organic acid uptake system (e.g. for glutarate) and an exchange of 


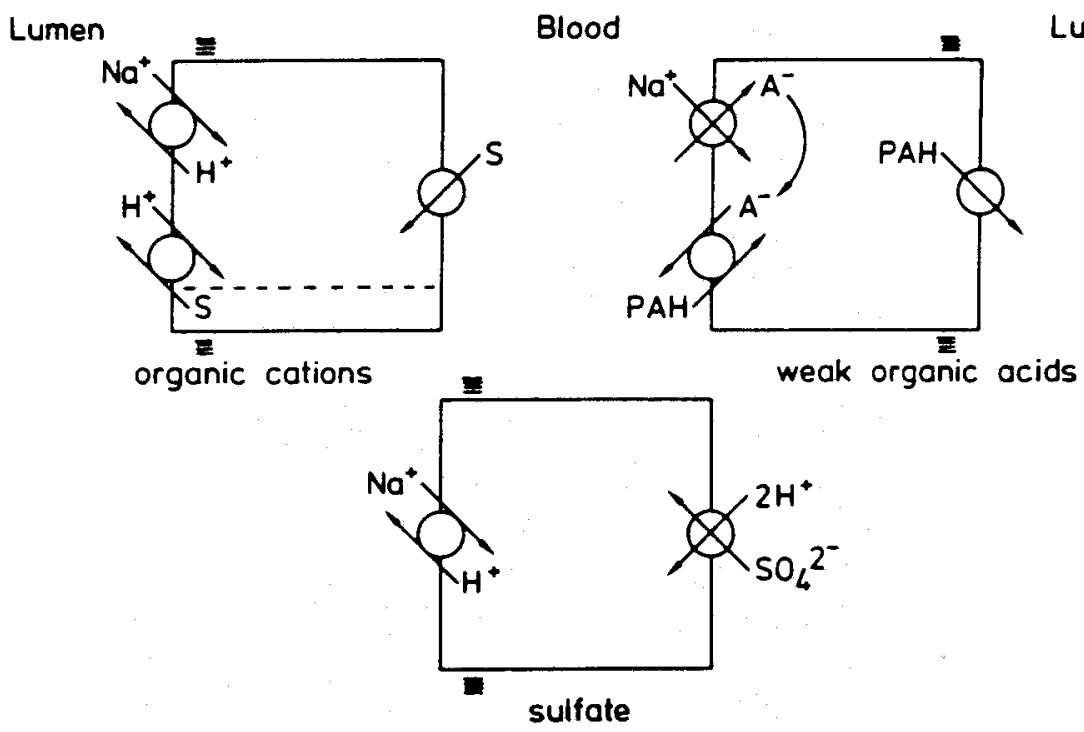

Fig. 3. Transport scheme for the secretion of the weak organic acid p-aminohippurate (PAH) across a proximal tubular cell (upper right panel). Uptake from blood into the cell involves indirect coupling to a sodium- $\mathrm{A}^{-}$cotransport system. ( $\mathrm{A}^{-}$. stands for glutarate or other dicarboxylic acids). Transfer across the luminal membrane involves an electrogenic transporter driven by the electrical potential difference across the cell membrane. The two other schemes show additional kinds of indirect coupling of sodium cotransport transport systems in the renal secretion of sulfate in winter flounder and organic cations (S) in mammals. For further information see Kinne, 1988a (reprinted with kind permission)

intracellularly accumulated glutarate with a weak organic acid, comprises the sequence of events that ultimately lead to the intracellular accumulation of the weak organic acid. Such a mechanism has proved to be operating also for example in the excretion of uric acid in crustaceans (A. Nies et al, unpubl. obs.) as well as in mammals (Maxild et al., 1981).

Figure 4 depicts the mechanisms involved in active chloride transport in the shark rectal gland and in the mammalian thick ascending limb of Henle's loop. This model was first proposed in 1985 (Epstein \& Silva, 1985) and experimentally proven in studies on the rectal gland and the flounder intestine (Kinne, 1988b; Kinne, 1991b). The essential elements of this model are the $\mathrm{Na}-\mathrm{K}-2 \mathrm{Cl}$ cotransporter which is responsible for the intracellular accumulation of chloride, the chloride channel through which chloride leaves the cell at the opposite side, the potassium channel which allows potassium to leave the cells and the above described Na-K-ATPase. This enzyme maintains the sodium gradient across the cell membranes and provides the primary driving force for the active transcellular chloride transport. It is interesting to note that one of the first indications of the involvement of the $\mathrm{Na}-\mathrm{K}-2 \mathrm{Cl}$ cotransporter in active chloride transport in the kidney, was an observation made by us during a stay at the Biologische Anstalt Helgoland In perfusion studies using rectal glands of Scilliorhinus canaliculus it could be shown that compounds strongly promoting salt secretion (or inhibiting salt reabsorption) in the mammalian kidney also strongly inhibited chloride transport in the rectal gland, as 

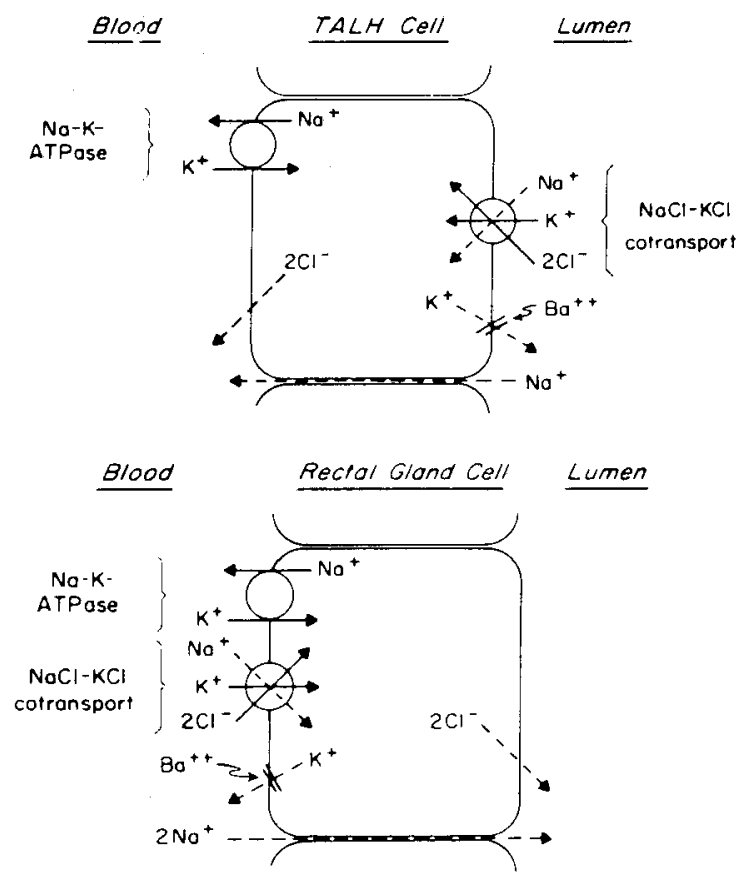

Fig. 4. Schematic representation of transcellular active chloride secretion in rectal gland cells of elasmobranchs and active chloride reabsorption in the thick ascending limb of Henle's loop in mammalians (modified after Epstein \& Silva, 1985, with kind permission)

documented in Figure 5 (Kinne \& Kinne-Saffran, 1979). This link led to a working model for active chloride transport in the mammalian thick ascending limb - and the operation of all the above mentioned transport systems could also be demonstrated in the kidney (Greger, 1985). It was further shown that these transport systems have similar properties - as depicted for the Na-K-2Cl cotransporter in Table 1 (Kinne, 1988a) - but that their cellular localization is different, in order to enable the mammalian cells to reabsorb chloride rather than to secrete chloride as the rectal gland cells do. To this end a Na-K$2 \mathrm{Cl}$ cotransporter and a potassium channel are known to be transferred into the luminal cell membrane, whereas a chloride channel is in the contraluminal membrane. Such transposition raises interesting questions on the molecular identity of the transport systems and the nature of the signals controlling their intracellular sorting and targeting (Simons \& Fuller, 1985) - questions currently being investigated - again using marine model systems.

Another group of diuretics, the thioziazides, are known to inhibit salt transport in the late distal tubule (see Figure 6; [Ellison et al., 1987]), a segment of very high cell heterogeneity in the mammals. Here the discovery of a similar transport system in flounder urinary bladder (Table 2, [Stokes et al., 1984]), a rather simple epithelium, will undoubtedly lead to a detailed characterization of the transport system and to a much better understanding of the mechanism of action of these drugs.

Finally, recent studies on the collecting duct have concentrated on the role of organis 


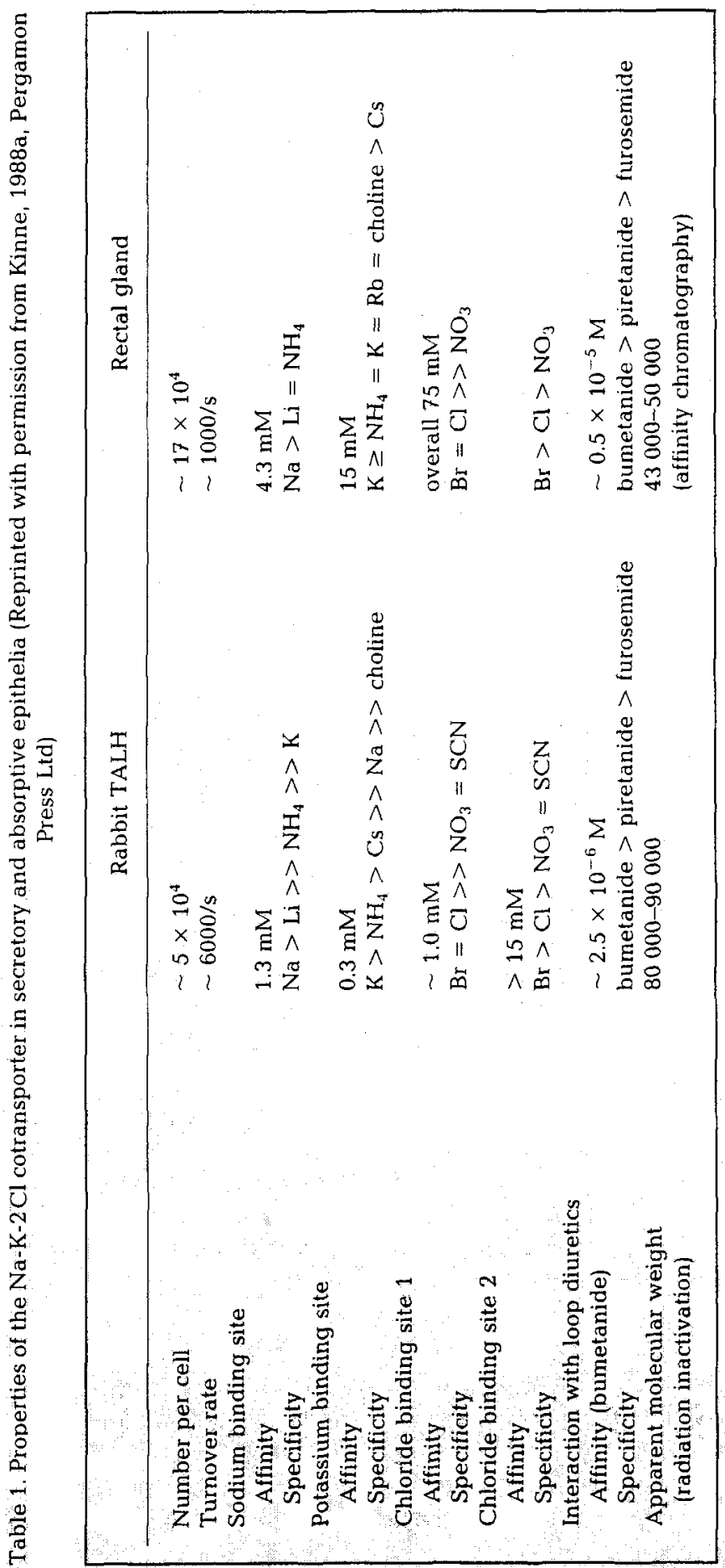




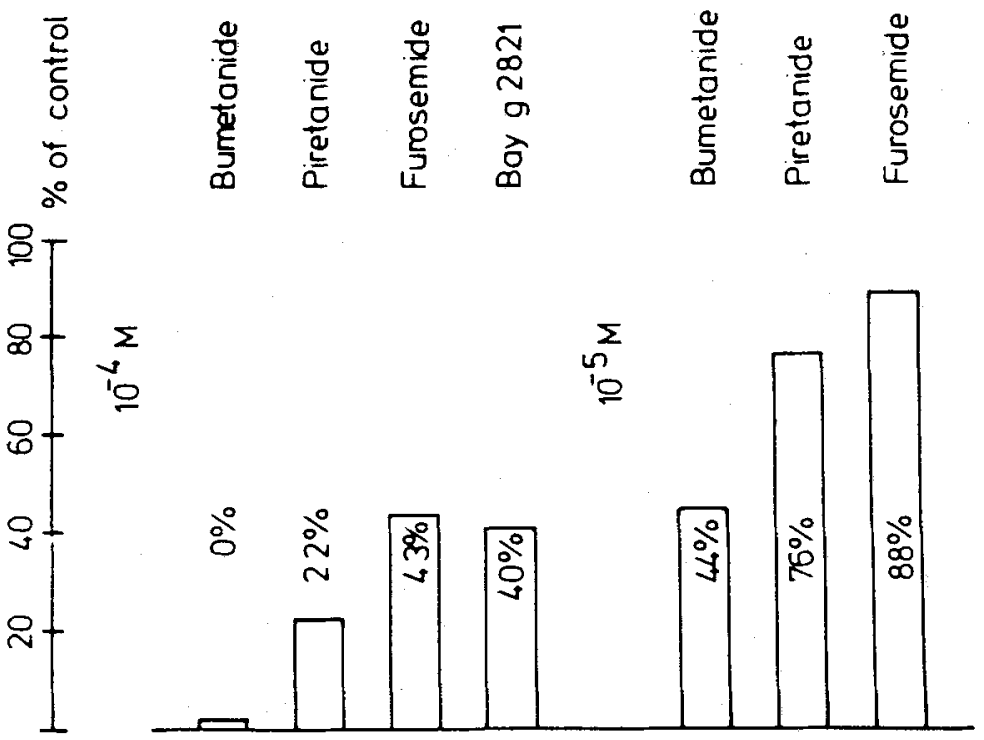

Fig. 5. Effects of various "loop diuretics" on the rate of fluid secretion (i.e. sodium chloride) in "in situ perfused" rectal glands of Scilliorrhinus caniculus (L.). Loop diuretics are known to inhibit chloride reabsorption in human kidney at the thick ascending limb of Henle's loop. Secretion at various concentrations of the diuretics is given in percent of control. For further details see Kinne \& Kinne-

Saffran, 1979 (reprinted with kind permission)
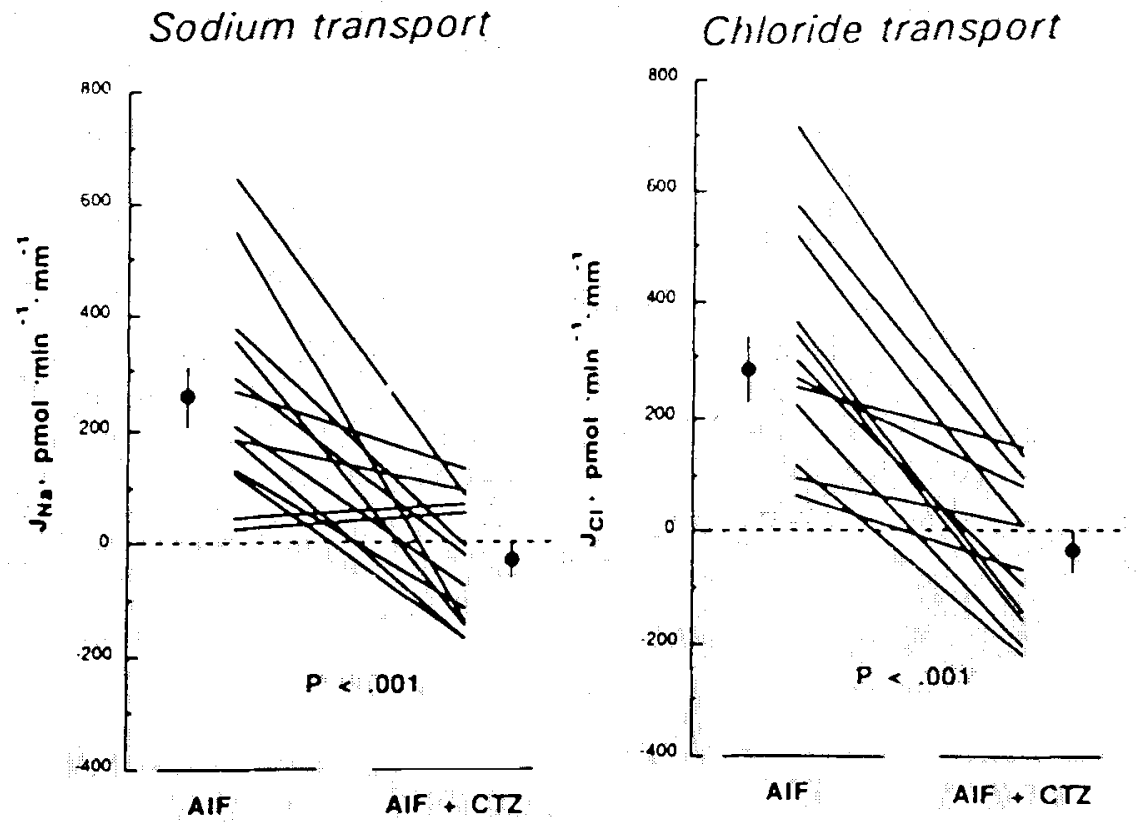

Fig. 6. Effect of chlorothiazide (CTZ) on salt reabsorption in distal tubules of rabbit kidney. Note that sodium and chloride transport are inhibited to the same extent, suggesting the presence of an electroneutral $\mathrm{NaCl}$ cotransport in this renal segment. For further information see Ellison et al., 1987 (reprinted with kind permission) 
Table 2. Effect of hydrochlorothiazide on simultaneously determined sodium and chloride tracer fluxes in the urinary bladder of the winter flounder (Pseudopleuronectes americanus). Mucosa-toserosa denotes the fluxes measured when tracer ions were present at the surface representing the lumen of the bladder; serosa-to-mucosa depicts fluxes when tracer ions were present at the outside of the bladder. Net fluxes represent the difference between the fluxes found in the mucosa-to-serosa direction and those observed in the serosa-to-mucosa direction. Note the similarity of sodium and chloride net fluxes and the parallel inhibition by hydrochlorothiazide. Modified after Stokes et al., 1984, with kind permission

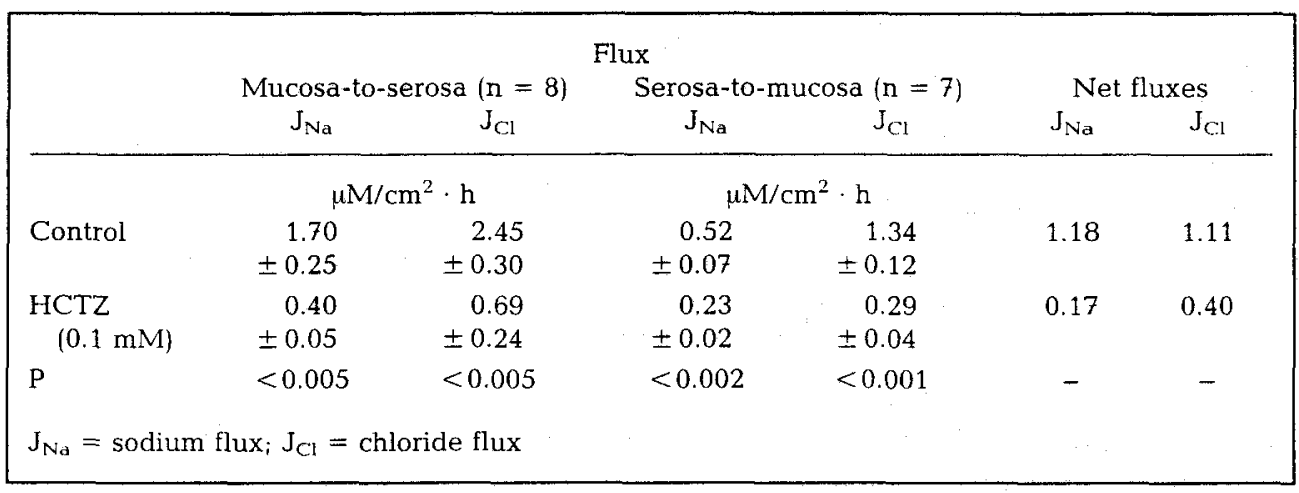

osmolytes in the volume regulation of these cells (Garcia-Perez \& Burg, 1991). During the formation of concentrated urine, these cells are exposed to salinities which are similar to or exceed those encountered by marine organisms. These organic osmolytes have for a long time already been identified in marine organisms (see Table 3; [Yancey et al., 1982]) and are also found in the mammalian papilla (Table 4). The regulation of their intracellular concentrations according to the external osmolarity has been extensively studied, for example in skate erythrocytes (Goldstein \& Brill, 1991). Again, numerous similarities have become apparent, and it is to be expected that the cross-talk between disciplines as in the other examples mentioned above - will yield fruitful and important insights into general physiological mechanisms.

\section{CONCLUDING REMARKS}

In the future, marine biological models will continue to foster progress in the understanding of molecular, cellular and systemic processes in biomedicine. Undoubtedly, a major impact will be made by studies on the molecular biology of basic physiological and pathophysiological events. At the same time, however, an equally strong emphasis should be placed on integrative aspects in marine biology and biomedicine alike; only the integration of knowledge obtained at various levels of complexity and in various areas of research will lead to a thorough understanding of life on this planet and to the development of strategies to protect it.

Acknowledgements. It is with great pleasure that we acknowledge the continuous, friendly and skillful support of the staff of the Biologische Anstalt Helgoland (BAH), in particular that of K.-H. Boysen, O. Goemann, F. Hennemann and G. Tadday. Special thanks go also to Professor Otto Kinne, the former Director of the $\mathrm{BAH}$. The conversations with him revealed a refreshing and encouraging degree of affinity regarding freedom of thought We also wouid like to thank D. Mägdefessel for skilfully organizing and polishing-up the manuscript. 
Table 3. Organic osmolytes in marine species. Taken from Yancey et al., 1982; copyright 1982 by the AAAS, with kind permission. For references see Yancey et al. 1982

Osmolyte system

Principal osmolytes

(occurrences)

Cyanobacteria

Synechococcus sp.

Fungi

Saccharomyces rouxii

Asteromyces cruciatus

Lichens

Lichina pygmeae

Unicellular algae

Dunaliella spp.

Chlorella pyrenoidosa

Ochromonas malhamensis

Multicellular algae

Fucus spp.

Vascular plants

Gossypium hirsutum L.

Insects (freeze-tolerant or -resistant)

Eurosta solidaginis (Diptera)

Bracon cephi (Hymenoptera)

Crustaceans

Artemia salina (emerging larvae)

Vertebrates

Hyla versicola

\section{A. Polyhydric alcohols-polyols}

glucosylglycerol

arabitol

arabitol, glycerol, mannitol

mannosidomannitol

glycerol

sucrose

isofloridoside

mannitol

glucose, fructose, sucrose

glycerol, sorbitol

glycerol

glycerol, trehalose

glycerol

\section{B. Amino acids and amino acid derivatives}

Eubacteria

Klebsiella aerogenes

Salmonella oranienburg

Streptococcus faecalis

Protozoa

Miemiensis avidus

Vascular plants

Spartina townsendii

Atriplex spongiosa

Aster tripolium

Mesembryanthemum nodiflorum

Invertebrates

All phyla of marine vertebrates

Balanus nubilus (barnacle)

Eriocheir sinensis (crab)

Parastichopus sp. (echinoderm)

Sepia officinalis (mollusk)

Cyclostomes

Myxine glutinosa (hagfish)

Amphibia

Bufo marinus glutamic acid, proline glutamic acid, proline $\gamma$-aminobutyric acid, proline

glycine, alanine, proline

betaine

betaine

proline

proline

various amino acids

various amino acids

various amino acids

various amino acids

various amino acids.

various amino acids 
Table 3 (continued)

Osmolyte system

Principal osmolytes

(occurrences)

\section{Urea and methylamines}

Cartilaginous fishes (elasmobranchs)

Vertebrates

Squalus acanthias (dogfish)

urea, trimethylamine-N-oxide

Dasyatis americana (ray)

Raja erinacea (ray) urea, trimethylamine- $\mathrm{N}$-oxide urea, amino acids

\section{Urea: estivating forms}

Mollusks

Bulimulus dealbatus

Lungfishes: African and South American

Amphibians

Scaphiopus couchi (spadefoot toad)

\section{E. Inorganic ions}

Archaebacteria

Halobacterium spp.

$\mathrm{K}^{+}$

Table 4. Osmolytes in renal inner medulla of antidiuretic animals. Units are $\mathrm{mmol} / \mathrm{kg}$ protein or $\mathrm{mmol} / \mathrm{kg}$ wet weight (in brackets). GPC = glycerophosphorylcholine. Taken from Garcia-Perez \& Burg, 1991, with kind permission. For references see Garcia-Perez \& Burg, 1991

\begin{tabular}{lcccccc|}
\hline Species & Urea & Sodium & Sorbitol & Inositol & GPC & Betaine \\
\hline Rabbit & & & {$[7]$} & {$[11]$} & {$[13]$} & {$[56]$} \\
& {$[269]$} & & {$[21]$} & {$[16]$} & {$[41]$} & {$[35]$} \\
& {$[346]$} & {$[279]$} & {$[80]$} & {$[42]$} \\
& 1.017 & 1.890 & 221 & 97 & 195 & 235 \\
Rat & & & {$[21]$} & {$[20]$} & {$[49]$} & \\
& {$[380]$} & {$[248]$} & 854 & 331 & 2.498 & 132 \\
& 4.405 & & & 178 & 517 & 214 \\
Vole & {$[349]$} & {$[171]$} & {$[26]$} & {$[14$} & 443 & {$[19]$} \\
Deer mouse & {$[695]$} & {$[278]$} & {$[19]$} & {$[14]$} & {$[63]$} & {$[19]$} \\
Pocket mouse & {$[1.129]$} & {$[350]$} & {$[53]$} & {$[14]$} & {$[71]$} & {$[50]$} \\
Sheep & & & {$[54]$} & & {$[67]$} & \\
Dog & {$[376]$} & {$[304]$} & & {$[14]$} & {$[18]$} & \\
& & & {$[2]$} & & {$[18]$} & \\
& & & & & & \\
\hline
\end{tabular}




\section{LITERATURE CITED}

Boron, W. F. \& Knakal, R. C., 1992. $\mathrm{Na}^{1+1}$-dependent $\mathrm{Cl}-\mathrm{HCO}_{3}$ exchange in the squid axon. - J. gen. Physiol. 99, 817-837.

Callard, G. V., 1991. Reproduction in male elasmobranch fishes. - Comp. Physiol. 10, 104-154.

Cushny, A. R., 1917. The secretion of urine. Longmans Green, London, 288 pp.

Ellison, D. H., Velázquez, H. \& Wright, F. S., 1987. Thiazide-sensitive sodium chloride cotransport in early distal tubule. - Am. J. Physiol. 253, F546-F554.

Epstein, F. H. \& Silva, P., 1985. Na-K-Cl cotransport in chloride-transporting epithelia. - Ann. N. Y. Acad. Sci. 456, 187-197.

Eveloff, J., Kinne, R. \& Kinter, W., 1979. p-Aminohippuric acid transport into brush border vesicles isolated from flounder kidney. - Am. J. Physiol. 237, F291-F298.

Forster, R. P. \& Taggart, J. V., 1950. Use of isolated renal tubules for the examination of metabolic processes associated with active cellular transport. - J. cell. comp. Physiol. 36, 251-270.

Garcia-Perez, A. \& Burg, M.B., 1991. Renal medullary organic osmolytes. - Physiol. Rev. 71, 1081-1115.

Goldstein, L. \& Brill S. R., 1991. Volume-activated taurine efflux from skate erythrocytes: possible band 3 involvement. - Am. J. Physiol. 260, R1014-R1020.

Greger, R., 1985. Ion transport mechanisms in thick ascending limb of Henle's loop of mammalian nephron. - Physiol. Rev. 65, 760-797.

Hodgkin, A. L. \& Huxley, A. F., 1952. A quantitative description of membrane current and its application to conduction and excitation in nerve. - J. Physiol. 117, 500-544.

Kinne, R. K. H., 1988a. Sodium cotransport systems in epithelial secretion. - Comp. Biochem. Physiol: 90A, 721-726.

Kinne, R., 1988b. The $\mathrm{Na} / \mathrm{K} / \mathrm{Cl}-$ cotransporter in epithelia: a personal reminiscence. - Bull. Mt Desert Isl. biol. Lab. 51-56.

Kinne, R. K. H., 1991a. From diversity to similarity in biological transport. - Issues Biomed. 15, 69-94.

Kinne, R. K. H., 1991b. Molecular properties of the Na-K-Cl cotransporter. In: Nephrology. Ed. by M. Hatano. Springer, Tokyo, 2, 1095-1102.

Kinne, R. \& Kinne-Saffran, E., 1979. Effect of 'loop diuretics' on the salt secretion in shark rectal gland. - Mar. Ecol. Prog. Ser. 1, 129-132.

Kinter, W. B., 1966. Chlorphenol red influx and efflux: microspectrophotometry of flounder kidney tubules. - Am. J. Physiol. 211, 1152-1164.

Kinter, W. B., 1975. Structure and function of renal tubules isolated from fish kidneys. - Fortschr. Zool. 23, 223-231.

Koob, T. J. \& Callard, I. P., 1991. Reproduction in female elasmobranchs, - Comp. Physiol, 10, 155-209.

Marshall, E. K. \& Grafflin, A. L., 1928. The structure and function of the kidney of Lophius piscatorius. - Bull. Johns Hopkins Hosp. 43, 205-235.

Marshall, E. K. \& Vickers, J. L., 1923. The mechanism of the elimination of phenosulphoneophthalein by the kidney - a proof of secretion by the convoluted tubiles. - Bull, Johns Hopkins Hosp. $34,1-16$.

Maxild, J., Møller, J. V. \& Sheikh, M. I., 1981. An energy-dependent, sodium-independent component of active p-aminohippurate transport in rabbit renal cortex. - J. Physiol., Lond. 310, 273-283.

Medzihradsky, F., Kline, M. H. \& Hokin, L. E., 1967. Studies on the characterization of the sodiumpotassium transport adenosinetriphosphatase. I.: Solubilization, stabilization, and estimation of apparent molecular weight: - Archs Biochem. Biophys 121, 311-316.

Pritchard, J. B., 1990. Rat renal cortical slices demonstrate p-aminohippurate/glutarate exchange and sodium/glutarate coupled p-aminohippurate transport - J. Pharmacol exp. Ther. 255, 969-975

Rappaport, R., 1991. Cytokinesis-Comp. Physiol. 10,1-36.

Schatzmann, H. J., 1967. Effect of cardiac glycosides on active Na-K-transport - Protoplasma 63; $136-142$.

Schofield, J.P., Jones, D. S. \& Forrest, J. N., 1991. Identification of C-type natriuretic peptide in heart of spiny dogfish shark (Squalus acanthias). - Am. J. Physiol 261, F734-F739. 
Shimada, H., Moewes, B. \& Burckhardt, G., 1987. Indirect coupling to $\mathrm{Na}^{+}$of $\mathrm{p}$-aminohippuric acid uptake into rat renal basolateral membrane vesicles. - Am. J. Physiol. 253, F795-F801.

Simons, K. \& Fuller, S.D., 1985. Cell surface polarity in epithelia. - A. Rev. Cell Biol. 1, 243-288.

Skou, J. C., 1957. The influence of some cations on the adenosine triphosphatase from peripheral nerves. - Biochim. biophys. Acta 23, 394-401.

Skou, J. C., 1989. The identification of the sodium-pump as the membrane-bound $\mathrm{Na}^{+} / \mathrm{K}^{+}$-ATPase: a commentary on 'The influence of some cations on an adenosine triphosphatase from peripheral nerves'. - Biochim. biophys. Acta 1000, 435-438.

Stokes, J. B., Lee, I. \& D'Amico, M., 1984. Sodium chloride absorption by the urinary bladder of the winter flounder. - J. clin. Invest. 74, 7-16.

Yancey, P. H., Clark, M. E., Hand, S. C., Bowlus, R. D. \& Somero, G. N., 1982. Living with water stress: evolution of osmolyte systems. - Science, N. Y. 217, 1214-1222. 